\title{
Objectivity, Fiction and New Media Digital Technologies Elaborated through Death'
}

In order to elaborate on such a proposal as is anticipated by the title of this article, I will, in the first part, analyse how this triadic format affects materialism, as "new materialism" is proposed as a substitute for what in the modernist era formed the relation between objectivity and materialism and realism, while in the second part I will expose the difference between thanatopolitics and necropolitics. ${ }^{1}$

\section{The Social as Anti-Totality}

New materialism presents a set of theoretical approaches that come right after the poststructuralist linguistic turn or cultural turn (developed in the last decades under the spell of the fluidity of language). New materialism tries to provide, with what is said to be affirmation over criticism, a new view on signification and the methodologies of knowledge and history. It is a path in theory and philosophy where ontology and epistemology are not divided but instead are in interaction with each other, and, therefore, the new materialism is becoming fluid, changing, reshaped, and remodelled.

The editors of the volume New Materialisms: Ontology, Agency, and Politics published in 2010, Diana Coole and Samantha Frost, asked imploringly, "How could we ignore the power of matter and the ways it materializes in our ordinary experiences or fail to acknowledge the primacy of matter in our theories?" claim that "the radicalism of the dominant discourses which have flourished

1 This article is a result of the research programme P6-0014 "Conditions and Problems of Contemporary Philosophy," the research project J6-9392 "The problem of objectivity and fiction in contemporary philosophy," and the research project J6-2589 "Structure and Genealogy of Perversion in Contemporary Philosophy, Politics, and Art,” which are funded by the Slovenian Research Agency.

2 Diana Coole and Samantha Frost (Eds.), New Materialisms: Ontology, Agency, and Politics, Duke University Press, Durham and London 2010, p. 1. 
under the cultural turn is now more or less exhausted.”3 They suggest utilizing diverse developments in digital technology, the natural sciences, biotechnology, the environment, the economy and health. Coole and Frost propose returning to the "materialist traditions developed prior to modernity" and avoiding the worldly determination of reality in order to find "fresh applications"4 of spiritualism. For the new materialists, the problem with the "cultural turn" is in part the "constructivist orientation" 5 of its theory, which treats matter as a social construction with no existence or agency independent of humans.

To enter the discussion, I will further summarize some of Kimberly DeFazio critical points of her re-evaluation in "The Spectral Ontology and Miraculous Materialism" on new materialism and how it operates at the present moment: "materialism in the 'new materialism' is largely a physicalist notion of matter (an experientialism which it justifies by allying itself with the discourses of natural science and phenomenology) and which is ideologically valuable precisely because it is 'a materialism which excludes the historical process'."' It is a form of

materialism that cannot explain the material world as a dialectical process whose motion may be positively and reliably understood. At the same time, the new post-historical materialism is elaborated through a ("new") posthumanist ontological framework that seems to offer an understanding of the social as a totality, emphasizing interlocking "webs" of connections between the social and natural world, and the "vital," corporeal "embeddedness" of the human in the nonhuman. [...]

Such allusions to totality of course have great appeal at a time when the global interconnections of social and natural life can no longer be avoided and when people struggle to understand the conditions to which their lives are ruthlessly subjected. But what is being offered by posthumanist ontology is in fact a theory blocking class understanding of issues in their material totality. It is a theory of "ecology" that empties the social out of the world, reducing it to physical and

3 Ibid., p. 6.

4 Ibid. p. 4.

5 Ibid.

6 Kimberly DeFazio, “The Spectral Ontology and Miraculous Materialism”, The Red Critique (15/2014), available at: http://www.redcritique.org/WinterSpring2014/spectralontologyandmiraculousmaterialism.htm. 
biological dynamics of local systems. Embeddedness and corporeality are ideological terms: their role is to limit knowledge to local knowledge and especially to the knowledge of experience. They are code words for anti-totality. It is not surprising, then, that the affirmation of individual experience and rejection of objectivity leads the new materialists to embrace spiritualism, the framework of which is rooted in individual beliefs and feelings.

[...] Posthumanist ontology, in other words, turns out to be a very familiar spectral ontology-an idealism.

“'Constructivist' accounts of matter," as argued by the new materialist critics, and as elucidated by DeFazio, are

no longer capable of addressing new realities like global climate change, ecological crisis, and growing economic disparities worldwide, not to mention the way new technologies and new scientific discoveries have meant that "unprecedented things are currently being done with and to matter, nature, life, production, and reproduction" through, for instance, biogenetics. ${ }^{8}$

Therefore, as explained by DeFazio, ${ }^{9}$ Coole and Frost "insist that the time has come for the return to materialism and the world of matter." 10 "Under the guise of a militant anti-theological return to the material world (which is needed to distinguish the new materialism from the Right's crude defense of theocracy), the new materialists," in the view of Coole and Frost, "advocate a subtle 'new' reading of the (spiritual) 'life' of matter."11

"[P]roponents of the new materialism," as pointed out by DeFazio, "express frustration with what Coole and Frost refer to as the "alergy to "the real"' of earlier textual approaches that has had the effect of discouraging 'critical inquirers from the more empirical investigation that material processes and structures require."” "They suggest that it is now necessary to address the ways in which the

\footnotetext{
7 Ibid.

8 Coole and Frost in DeFazio, New Materialisms.

9 DeFazio, “The Spectral Ontology”.

10 Coole and Frost, New Materialisms, p. 3.

${ }_{11}$ DeFazio, "The Spectral Ontology".

12 Ibid.
} 
material world - the world not just of objects, nature, and the human body, but such phenomena as 'the electricity grid, food, and trash' [...]-has an 'agency' which has hitherto not been accounted for." ${ }^{13}$ In fact, Coole and Frost, as argued by DeFazio, “joyfully affirm the new materialism because its 'post-dualism' means that there can be 'no definitive break between [...] material and spiritual phenomena." "14

Therefore, to summarize schematically, DeFazio argues that "the new materialism, consequently, is not a rejection but an updating of the culturalism that has played an integral role in dismantling the materialist critique of capitalism in the postwar era," where "the relation between subject and object [...] reflects a deep confusion about, if not a deliberate rewriting of, some of the 'fundamental questions' of materialism and thus have profoundly problematic implications for materialism and the struggle for a world organized on the basis of meeting social needs." ${ }^{15}$

With this in mind, I would like to emphasize two main points that are crucial for understanding what the new materialism does. Firstly, it repudiates the human, simply saying that it is time to get rid of the humanist perspective and the humanist position in seeing and correlating with the world. Secondly, it repudiates history, practices, and ideas, as stated by DeFazio, in order to isolate ideas and practices from the material relations of history while highlighting "the cellular, molecular, subatomic, and cosmic levels." ${ }^{16}$

As what is produced in new materialism according to the criticism developed by DeFazio, is a "posthumanist ontology," ${ }_{17}$ a theory that prevents a class (and I also underline race and gender, but more on this below) understanding of issues in their material totality. On the other hand, posthumanists "place us into radical relationality with other species, with whom we have co-evolved and continue to co-exist." ${ }^{18}$ As Francesca Ferrando exposed, "New materialism is anoth-

\footnotetext{
Ibid.

4 Ibid.

15 Ibid.

16 Ibid.

${ }_{17}$ Ibid.

18 Lucian Gomoll, “Posthuman Performance: A Feminist Intervention”, Total Art Journal 1, (1/2011), available at: http://totalartjournal.com/archives/1764/posthuman-performance/.
} 
er specific movement within the posthumanist theoretical scenario." ${ }^{19}$ At this point it is important to shed light on the terminology. In a review of Cary Wolfe's What is Posthumanism? Joshua (Sha) LaBare claims that "[w]hile transhumanism actively embraces the matter/information dualism-proposing to transcend the human condition by somehow leaving the body behind-posthumanism, in the sense Wolfe gives it, rejects the very liberal humanist imaginary that makes that dualism possible. In short, Wolfe's posthumanism can be seen as a rallying cry for a poststructuralist approach that aspires to fully comprehend what amounts to a new reality: that the human occupies a new place in the universe, a universe now populated by what I am prepared to call nonhuman subjects." 20

\section{Racialized Society}

Therefore, the critique that I will offer puts itself in opposition to 000 (object-oriented ontology) ${ }^{21}$ and treats NGC (neoliberal global capitalism) as an object of research, as well as capital maximization of surplus value (making a profit and further maximizing it) and the consequent process of the privatization of everything and everybody. I will do this by exposing two major features of NGC lurking behind the new materialism, the logic of the humanization of capital, and the evacuation of history due to the flexibilization of power relations in capitalism. The latter is the ability of capitalism to depoliticize, or more accurately, de-historicize hierarchical and vertical relations of power, and to reduce the rigidity of political control over society, quite perversely, in the name of "humanity." 22 These two NGC processes present the political subject as non-existent, and it makes us wonder who this "human" is.

Modern scientific revolutions present the NGC system as being apart from history, or above history, preventing the possibility of historicizing the genealogy

19 Francesca Ferrando, "Posthumanism, Transhumanism, Antihumanism, Metahumanism, and New Materialisms: Differences and Relations”, Existenz 8 (2/2013, p. 30.

20 Joshua (Sha) LaBare, “Review of What is Posthumanism?", Science Fiction Film and Television 4 (1/2011), pp. 136-137.

${ }^{21}$ Graham Harman, Object-Oriented Ontology: A New Theory of Everything, Penguin Books Ltd, London 2018.

22 See Marina Gržinić and Šefik Tatlić, Necropolitics, Racialization, and Global Capitalism: Historicization of Biopolitics and Forensics of Politics, Art, and Life, Lexington Books, Lanham 2014 . 
of the "human" (precisely for being an ideologically racialized category) and understanding clearly that the present moment of the logic of the humanization of capital started with capitalism and its political project in the $15^{\text {th }}$ century (colonialism). In the late twentieth century, in the era of neoliberal capitalism, as the dominant model of the organization of exploitation, we see a complete distortion of "humans" within NGC. The relationship between the oppressor and the oppressed is pacified and defined as a partnership. This occurs under the conditions in which capitalism is defined as a "post-ideological" project, in an era defined as the "end of history," which creates the implication that that social conflict/antagonism in capitalism has ended. We have racialized labour divisions, and naturalized histories of colonialism and contemporary forms of coloniality (colonialism without colonies). These processes are an outcome of capital's racialization (a system of racism, discrimination, and dispossession) and are directly connected with the nearly forgotten colonialism and its almost universalized and accepted imperial war machine, and the militarization of every level of the social, economic, and political in the present state of neoliberal financial global capitalism. NGC, with its processes of financialization, appropriates the places of politics, the social, economic, as well as theory and culture, for direct money laundering, while also heavily exploiting the new economy of attention that uses affective labour as an intrinsic part of the system of reproduction of global capitalism in a form of unprecedented dimensions for the new neoliberal global accumulation of capital and power. At the epicentre we see the financialization of life and labour, and the militarization of life, politics, and labour, where the "human" is a direct result of the capitalist war machine.

As Donna Haraway stated in her "A Cyborg Manifesto: Science, Technology and Socialist-Feminism in the Late Twentieth Century," ${ }^{24}$ published in Socialist Review in 1985, we are transitioning from "the comfortable old hierarchical dominations" to the "scary new networks" that she calls "the informatics of domination." ${ }^{25}$ Some of these disturbing networks include neo-imperialism,

${ }^{23}$ Aníbal Quijano, “Coloniality and Modernity/Rationality,” Cultural Studies 21, (2-3/2007), pp. $168-178$.

24 Donna Haraway, "Manifesto for Cyborgs: Science, Technology, and Social Feminism in the 1980s," Socialist Review 80 (1985), pp. 65-108. Reprinted as “A Cyborg Manifesto: Science, Technology and Socialist-Feminism in the Late Twentieth Century”, in: Simians, Cyborgs, and Women: The Re-invention of Nature, Free Association Press, London 1991, pp. 149-182.

25 Ibid., p. 161. 
population control, and communications engineering - but these intimidating systems are not meant to be seen as monoliths, nor does she present technology as automatically coercive. Haraway talks about the social relations of science and technology in order to point out that we are not dealing with technological determinism; the interaction is much more dynamic than that. Rather than seeing our lives as determined and structured by technology that is beyond our control, she says that we need to see what sources of power we can find in that technology, and use it in creative and political ways. We face a political situation of death and corruption that presupposes an unspoken permissibility for wars, mass murder, and torture. ${ }^{26}$ The power of coloniality, as a structure of control, lies in speaking so forcefully that we see no alternative but to accept it, thus dispensing with human life.

One of the most tangible passages in this drawing of the genealogy of the NGC, and therefore the genealogy of the new materialism, is the shift from biopolitics to necropolitics. Biopolitics, coined by Michel Foucault ${ }^{27}$ in the 1970 s as a mode of governing and managing life, which I translate (as briefly as possible) into "make live and let die," was a way of governing life intended exclusively for the capitalist First (Western) World. Due to the pressing socialism all around it, the First Capitalist World in the 1970s provided (although under hidden regimes of discipline for its fellow Western citizens), comfortable life facilities, but almost exclusively for those perceived as "natural" citizens of the respective First-World capitalist nation-states. The other worlds were left to die, as they were outside of the interest of the First Capitalist World, until from time to time (and with varying frequency), of course, it was necessary for the former imperial and colonial nation-states, which were also all antisemitic states, to suppress the decolonization struggles or attack socialism with military or paramilitary forces. This was the case when the "absolute democracy" of private property and surplus value, the two fundamental pillars of capitalism, were put into question.

At the same time, migrants (both economic and political refugees) in the First Capitalist World (the strained relations between Latin America and the US are

26 Steve Martinot, “The Coloniality of Power: Notes Toward De-Colonization”, Open Computing Facility, available at: https://www.ocf.berkeley.edu/ marto/coloniality.htm.

${ }_{27}$ See Michel Foucault, The Foucault Effect: Studies of Governmentality, The University of Chicago Press, Chicago 1991. 
at the centre of these discussions) have gone from their non-existent position in the past to an overtly and continually criminalized second-class and non-citizen status in the present.

However, what we see today is a brutal intensification of the biopolitical regime of life from the 1970s. This intensification was named necropolitics by Achille Mbembe. ${ }^{28}$

It was conceptualized by Mbembe in 2003 based on his analysis of the condition of Africa as a post-colony. Necropolitics centres on new capital's logic and its processes of the geopolitical demarcation of world zones, which are based on mobilization of the war machine; necropolitics' accumulation of capital is a result of the total dispossession and subjugation of life to the power of death. Therefore, if Foucault's biopolitics, a term in-between bio (life) and politics, can be designated in an axiomatic way as "make live and let die," then necropolitics, a term in-between necro (death) and politics, can be designated in an axiomatic way as "let live and make die." There is a huge difference between "make live," providing structures and facilities for life, and just "let live." The latter presents the structure of the pure biopolitics of abandonment that is, in fact, necropolitics. The necropolitical now also punishes the natural nation-state citizens that are abandoned in the meanderings of laws and administrative provisions, where the lives of those coming from so-called "third states" and their partners become caught in vicious regimes of poverty, deprivation, and seclusion. Furthermore, aesthetic contradictions are profoundly re/articulated within the intensified militarization and racialization of our lives. Initially, I exposed a process of de-historicization that is at stake here.

In The Production of Difference: Race and the Management of Labor in U.S. History, ${ }^{29}$ written by David R. Roediger and Elizabeth D. Esch, and reviewed by Joe R. Feagin, the authors probe deeply into the relationship of institutionalized racism with the management of labour in the United States. As they emphasize, "race management" has been a much neglected topic in the social sciences. ${ }^{30}$

28 Achille Mbembe, "Necropolitics", Public Culture 15, (1/2003), pp. 11-40.

29 David R. Roediger and Elizabeth D. Esch, The Production of Difference: Race and the Management of Labor in U.S. History, Oxford University Press, New York 2012.

30 Joe R. Feagin, "Whiteness as a Managerial System: Race and the Control of U.S. Labor," Monthly Review 64 (8/2013), http://monthlyreview.org/author/joerfeagin/. 
Some analysts, as commented by Joe R. Feagin, might suggest that this centrality of white-racist framing and related action in a critical era for the development of capitalistic management theory and practice is just a leftover from pre-modern impulses and efforts that will soon end, but Roediger and Esch reject that interpretation, and demonstrate that capitalistic management has for many decades, even to the present day, used the "irrationalities of race" to manage labour and much else in capitalistic economies. ${ }^{31}$

Racialized "humans" (this new category of nonhumans) are formed by new populations of poor people, populations of those seen as less human. These racialized populations are the new class. It is clear that neoliberal global financial capitalism, with its regime of whiteness, exponentially develops the processes of the abandonment of the structures of life and ferociously rejects demands for equality and life improvement.

The imperial, colonial, racial division, although expelled violently from global financial capitalism, is returning with a vengeance, in the $\mathrm{OOO}$ setting as well, through racialized labour theory and the racialized Other. Thinkers engaged in the new materialism, speculative realism, non-representational theory, constructivist philosophy, and posthumanism, when engaging critically with race and gender, accomplish this task through rethinking race as a material ontology and as assemblage theory. Assemblage theory is used in order to challenge and extend the concept of intersectionality. Here also lie the possibilities and potentialities.

Transgressing boundaries is essential to Donna Haraway's conception of the cyborg. She says, "[a] cyborg is a cybernetic organism, a hybrid of machine and organism, a creature of social reality as well as a creature of fiction. Social reality is lived social relations, our most important political construction, a world-changing fiction. ${ }^{32}$ At first it may seem abstract to think of a person - if a cyborg is meant to be the model for a new, posthuman kind of person - who is at once organic and mechanical, artificial and natural, real and fictional. When the boundaries are blurred between the "natural" and "artificial" parts of what

\footnotetext{
31 Ibid.

32 Haraway, Simians, Cyborgs, and Women: The Re-invention of Nature, p. 149.
} 
makes us human, it becomes much harder to take "nature" for granted, and a whole array of assumptions are undermined.

Therefore, although the critique that $\mathrm{OOO}$ and the new materialism give legitimacy to a specific kind of politics that is non-anthropocentric and works hand in hand with a dangerous de/historicization and de/politicization has already been put forward, what I want to emphasize is that OOO's objectification and commodification of humans incites the topic of the non-human. The relation is no longer between the human and commodity, but between objects and the non-human, as capital's objects, goods are now at the centre of the processes of humanization. Racialization becomes the main form of differentiation in such a defined "society" and all those subjugated to it are tied under the brand of the "common destiny of humanity." By analysing the genealogy of these processes in such a situation, it becomes clear that NGC has to insist on the posthuman as the human, since history and agency are completely co-opted, regulated, and reproduced under the order of the capitalist reproduction of exploitation, expropriation, and dispossession. It would be very unpleasant to leave the terrain of research open, and to be confronted with the state of things through a serious analysis within academic spheres. It is much more convenient to shift the discourse elsewhere into the post-human, as the human is transformed through the logic of the humanization of capital into something that is just biological matter.

If we insist on the analysis of the "human" (which also has to be analysed very carefully since "the human" is an ideological category par excellence, reproduced firmly by capital), we will see that there is a brutal logic of the dispossession of capital waiting for us at the centre of NGC and its contemporary discourses. As stated by Francesca Ferrando about bell hooks, 33 "[a]s posthumanism attracts more attention and becomes mainstream, new challenges arise." ${ }^{34}$ For example, some thinkers are currently looking to embrace "exotic" differences, such as robots, biotechnological chimeras, aliens, without having to deal with the differences embedded within the human realm.

See bell hooks, Feminist Theory: From Margin to Center, South End Press, Boston 1984.

34 Ferrando, "Posthumanism, Transhumanism, Antihumanism, Metahumanism, and New Materialism”, p. 30 


\section{Social Anti-Matter}

My initial objective of addressing objectivity and fiction and new media technology through death (i.e. how the development of technologies has affected the status of the fundamental relationships between reality and fiction, visibility and invisibility, true image and false information, etc.) is based on a proposal to think of all these modernist categories from the "optics" of necropolitics. Necropolitics confronts us with the horrors of the human condition: death and killing, forced enclosure, total abandonment. If we think precisely about what is going on at the border between the European Union/Greece and Turkey, we can see a new relation about life and death where the colonial/racial division is applied. Those at the border come from states destroyed by imperialist Occidental appetites and racial differentiation between the white occident and the other parts of world that are viewed as illegitimate members of the regime of whiteness ${ }^{35}$ and its colonial matrix of power that extends from the past to the present day.

Death itself, as I presented above, has become a fallacious rite of passage in modernity's instrumentalization of humanity. This has, in retrospect, terminal consequences for how technology and new media technology change time and space and the social sphere.

I developed some of these theses in the 1990s regarding the overdetermination of time over space, overdetermination in the sense proposed by Louis Althusser, which was made possible by new media and digital technologies (the internet was accessible to Occidental citizens in 1993).

Following the 1930 and 1940s, after decades of accelerated change, the holocaust of Hiroshima and Nagasaki, deleted, at least symbolically, the concept of the future. If the future died in the 1940 s with the explosion of the atomic bomb,

35 See Paul Gilroy, “There Ain't No Black in the Union Jack”: The Cultural Politics of Race and Nation, University of Chicago Press, Chicago 1991; Paul Gilroy, Against Race: Imagining Political Culture beyond the Color Line, Harvard University Press, Cambridge, Massachusetts 2000; Saidiya V. Hartman, Scenes of Subjection: Terror, Slavery, and Self-Making in Nineteenth-Century America, Oxford University Press, New York 1997; Bell Hooks, "Representing Whiteness in the Black Imagination”, Cultural Studies, ed. L. Grossberg, C. Nelson, P. A. Treichler, Routledge, New York 1992, pp. 338-342. 
in the 1970 seople literally lost interest in the future, as well as in the past. ${ }^{36}$ From the 1990 on on, according to Peter Weibel, we have been able to think about a relation when we leave a historically defined position which imitates (even in the arts) the natural world of our senses. ${ }^{37}$ Our experience of place, position, and so on depends on what we call the natural interface: the body is, for example, a natural interface, and therefore we have a natural approach to space and time. Our interpretation of the media is experienced through natural interfaces. Our senses and organs are channelled and mediated by an ideology of naturality, neglecting the artificiality of the media. But the media of our time shows us that we have the possibility of an artificial interface, which is the media. According to Weibel, when McLuhan defined media as an extension of man, he just missed calling it an artificial extension..$^{8}$ And in this artificial media space, we see that the basic concept of how to construct space and time are examples of non-naturality. The media world is dominated by non-identity, or difference.

Santiago López Petit states that this "difference" which was, in the not-so-distant past, known as social antagonism (class struggle), has been divided today within itself into order and disorder. In such a way the unity of levels is maintained and reality is made multiple. ${ }^{39}$ In such a way we can also read the primacy of difference, but, as stated by López Petit, this difference is now pushed forward, pointing to the sameness that is the appendix of the rearticulation of difference. This identity, or sameness, is today the established co-propriety of capital/power that takes on very different names, depending on the specific social and political space..$^{40}$

Necessity is replaced by contingency.

36 Marina Gržinić, V vrsti za virtualni kruh: čas, prostor, subjekt in novi mediji v letu 2000 [In line for virtual bread: Time, space, subject, and new media in the year 2000], Znanstveno in publicistično središče, Ljubljana 1996.

37 Peter Weibel, "Ways of Contextualisation, or The Exhibition as a Discrete Machine”, in Place, Position, Presentation Public, ed. I. Gevers, Jan van Eyck Akademie and De Balie, Maastricht and Amsterdam 1993, p. 225.

38 Ibid.

39 Santiago López Petit, La movilización global: Breve tratado para atacar la realidad [Global mobilisation: A brief treatise for attacking reality], Editorial Traficantes de Sueños, Barcelona 2009, p. 38.

40 Gržinić and Tatlić, Necropolitics, Racialization, and Global Capitalism, p. 143. 
In the "old world" of the social, via Arthur Kroker and David Cook, ${ }^{41}$ an emancipatory politics entailed the production of meaning: the control of individual and collective perspectives against a normalizing society that sought to exclude its oppositions. Society was constructed on the notion of the emancipatory subject who demanded rightful inclusion in the contractual space of the political economy..$^{42}$ Kroker and Cook, through a re-reading of Baudrillard, exposed already in the 1980 os that what should be expected is the collapse of the normalizing, expanding, and positive cycle of the social into its opposite: an implosive and structural order of signs. Again, I worked on these theses at the beginning of the $1990 \mathrm{os},{ }^{43}$ although at that time, in the postsocialist condition of life and theory, this was a purely fictional scenario, or better put, a science fiction. The triumph of signifying culture entails the eclipse of genuine social solidarities. ${ }^{44}$ We face a kind of exteriorization where strategies of normalization are replaced by the simulation of the masses. Here the "hyper-reality" of culture indicates a great dissolution of the space of the social. ${ }^{45}$

Already back in the 1980 os Baudrillard explored the brutal processes of de-historicization and de-socialization, which structure the new communicative order of the signifying culture. ${ }^{46}$ In the Shadow of the Silent Majorities, Baudrillard provides three strategic hypotheses about the existence of the social, all with murderous effect. The first hypothesis is that the social may only refer to the space of delusion; the social has basically never existed. The second hypothesis sees the social as a residuum, and the third the end of the "perspective space of the social." ${ }^{\prime 7}$ One consequence is that, if the social is a simulation, then the likely course of events (massacres, rapes, etc.) is a brutal de-simulation. This is the way, for example, that the war in 1990s in Bosnia and Herzegovina was perceived.

${ }^{41}$ Arthur Kroker and David Cook, The Postmodern Scene: Excremental Culture and HyperAesthetics, St. Martin's Press, New York 1986.

42 Ibid., p. 175.

43 See also Marina Gržinič, "Real and Virtual Spaces: Confrontations and Exchange", 2005, available at: https://www.helsinki.fi/sites/default/files/atoms/files/grzinic.pdf.

44 Arthur Kroker and David Cook, The Postmodern Scene: Excremental Culture and HyperAesthetics, pp. 172-173.

45 Jean Baudrillard, In the Shadow of the Silent Majorities, Jean Baudrillard and Semiotext(e), New York 1983, pp. 3-4.

46 Kroker and Cook, The Postmodern Scene, p. 175.

47 Baudrillard, In the Shadow of the Silent Majorities, pp. 3-4. 
The above also refers to two of the four great refusals of Jean Baudrillard concerning the classical (or perhaps rather "modernist") models of society's functioning: a rejection of the naturalistic discourse of the historical, and a rupture with the normalizing order of reality, and hence an accumulative conception of power. ${ }^{48}$ For Kroker and Cook, in the 1980 os, television, already, is not just a technical ensemble, a social apparatus, which implodes into society as the emblematic cultural form of a relational power. Television's major form of social cohesion is provided by the pseudo-solidarities of electronic television images, whose public is, according to Baudrillard, the dark, silent mass of viewers. They are never permitted to speak while the media elite, which is allowed to speak, "has nothing to say." The explosion of information and the implosion of meaning are the keynote of mass communication; a massive circularity in which the sender is the receiver, an irreversible medium of communication without response. Such is the strategic consequence of television manipulating the society. ${ }^{49}$ The TV audience has already been described as the most pervasive type of social community. If this is so, then it is an anti-community, a social anti-matter, an electronic mall that privileges the psychological position of the voyeur, a society of the disembodied eye, or the cultural position of the tourist in a society of spectacle..$^{\circ}$ What else are Western Europe, European peace movements, civil associations, and, last but not least, millions of TV viewers and other squatters but social anti-matter? Baudrillard's hypotheses about the media in connection with hyper-reality and simulation, so ferociously criticized by "serious" philosophers as to be a theoretical simulation (almost science fiction) seem, in the context of proxy wars, the complete abandonment of refugees, and the arrest of democratic processes, to warrant serious re-evaluation.

Baudrillard described the current mood in Simulacra and Simulation: "Melancholia is the inherent quality of the mode of disappearance of meaning, of the mode of the volatilization of meaning in operational systems. And we are all melancholic. ${ }^{{ }^{11}}$ Martin Jay, in his book, Force Fields, ${ }^{52}$ refers to a similar idea in the

\footnotetext{
48 Kroker and Cook, The Postmodern Scene, p. 171.

49 Ibid., p. 176.

50 Ibid., p. 274.

51 Jean Baudrillard, Simulacra and Simulation, trans. S. Faria Glaser, The University of Michigan Press, Ann Arbor 1994, p. 162.

52 Martin Jay, Force Fields: Between Intellectual History and Cultural Critique, Routledge, New York and London 1993.
} 
Derridean coinage "destinerrance," which suggests the impossibility of messages ever reaching their assigned destinations. Melancholia is thus, Jay suggests, not simply an illness, but a kind of permanent dimension of the human condition. A great number of authors distinguish between melancholia and mourning, which are not specific states of mind, but two different attitudes toward the world. In relation to Freud's text "Mourning and Mania" from 1917, Jay points out that the refusal to test reality can still help us make sense of the distinction between mourning and melancholy. It is precisely the ability to do so that distinguishes the former from the latter. ${ }^{33}$ Melancholy, with its manic-depressive symptoms, suggests the inability to mourn, or to reflect reality. "Melancholy," wrote Jay, "seems to follow the logic of what Freud calls elsewhere disavowal or foreclosure (Verwerfung), in which inassimilable material seems to be cast out of the psyche and reappears in the realm of a hallucinatory 'real." ${ }_{54}$ Instead of being able to consciously identify what actually has been lost, he or she "remains caught in a perpetually unsubstantiated dialectic of self-punishing fear and manic denial." ${ }^{55}$ Some traits of these definitions of melancholy can apply directly to what we have witnessed in 2020, at this present moment (Nov. 2020), as Donald Trump shows no sign of conceding defeat after losing the US presidential election to Joe Biden. The Trump administration is acting like a dictatorship in the USA as Trump denies election defeat. While Trump himself, is caught in a perpetually unsubstantiated dialectic of maniacal denial and a massive psychotic scenario of accusations.

The "paradigm" of melancholy that I analysed in the mid-199os functioned like an analytical tool to shed light on the mode by which (Western) Europe and its civil institutions dealt with the war in the territory of ex-Yugoslavia, especially in Bosnia and Herzegovina in the 1990s. This resulted in the Srebrenica genocide ${ }^{56}$

53 Ibid., p. 93.

54 Ibid.

55 Ibid.

56 The Srebrenica genocide was the massacre of more than 8,00o Bosniaks (Bosnian Muslims), boys and men, in July 1995 during the Balkan wars. The executions were carried out by the Army of Republika Srpska (VRS), which attacked the town of Srebrenica in eastern Bosnia and Herzegovina. See International Criminal Tribune for the Former Yugoslavia, "Srebrenica Genocide: No Room for Denial”, available at: https://www.icty.org/en/outreach/ documentaries/srebrenica-genocide-no-room-for-denial (accessed 16 November 2020). 
The questions that such hypotheses raise are obvious: What is the object (or objects) whose loss cannot be confronted? Why does it remain so resolutely disavowed and so resistant to a conscious working through? ${ }^{57}$ We are trying to locate a specific historical trauma that resists the mourning process. According to Jay:

[...] monotheistic religions like Judaism and Christianity sought to replace their mother-goddess predecessors with a stern patriarchal deity, then perhaps the lost object can be understood as in some sense maternal. Mourning would mean working through the loss produced by the archaic mother's disappearance. An inability to renounce the regressive desire to reunite with the mother in a fantasy of recaptured plenitude, when accompanied by the unconscious self-reproach that her death was covertly desired, would result in melancholia instead..$^{58}$

The Muslim reality in Europe, if I may cynically paraphrase Derrida, is understood like both a poison and a cure.

Mourning is important, as it allows us the strategic and emotional process of reflexivity, which enables us to survive this transitional period. On the other hand, mourning as a complete working through of lost material, is itself a utopian myth. "[T]he hope of finding a means to [completely] transcend the repetition and displacement characteristic of apocalyptic melancholia is necessarily doomed to failure. ${ }^{\prime 9}$

And a consequence of the new media technology and digital social platforms is that social media sites such as Facebook and Twitter have become new sites associated with narcissistic tendencies. Social networks are an ideal stage for narcissists to showcase themselves, but also a reservoir for the dissemination of the most terrifying, violent populist and right-wing thoughts.

Pierre Lévy ${ }^{60}$ has pointed out in exactly the same manner that up until now we have mainly envisaged virtual realities as simulating physical spaces.

57 Jay, Force Fields, p. 94.

58 Ibid.

59 Ibid. p. 97.

60 Pierre Lévy, “Toward Super-language”, in: ISEA 94: The $5^{\text {th }}$ International Symposium on Electronic Art Catalogue, ed. Minna Tarkka, University of Art and Design Helsinki, Helsinki 1994, pp. 10-17. 
Alternatively, we need to speak of the production of symbolic spaces in the form of virtual worlds as expressive of significations, and of knowledge characteristic of a collectivity. These virtual worlds, as Levy declares, express acts of collective communication in real time, with the direct involvement of, and the tactile component suggested by, words. The deepened split between the physical realities, including the dangers of urban life and the phantasmatic world of "on-line" sociality, is both encouraging and depressive.

In the age of new media and digital technologies we see an entanglement of ecstasy and decay, hyper-primitivism and hyper-imaging.

I have tried to show that virtual reality cannot be reduced to a mere technological or a discursive object. It is a complex social amalgam, in which its existence as a textual figure is inseparable from its machinist use.

\section{The New Melancholy and the Vertiginous Presence of Death}

Massimo Recalcati, in his Le nuove melanconie: Destini del desiderio nel tempo ipermoderno ${ }^{61}$ says that melancholy is no longer what it used to be, that melancholy, as Freud argued, still involved some sense of guilt; today, however, melancholy has acquired new declinations, characterized by a fundamental lack of awareness of life and also of maintaining life in its transmission from one generation to the next. Freud talks about melancholy; ${ }^{62}$ the old melancholy brings a feeling of guilt in front of laws that are too severe, but contemporary melancholy stems from an incapacity to give meaning to the - I will add "Occidental" - experience.

In the Occident, the relation between subject and object can be put in a genealogy as a series of discontinued modalities.

61 Massimo Recalcati, Le nuove melanconie: Destini del desiderio nel tempo ipermoderno [The new melancholies: Fates of desire in hypermodern times], Raffaello Cortina Editore, Milano 2019.

62 Sigmund Freud, "Mourning and Melancholia", in The Standard Edition of the Complete Psychological Works of Sigmund Freud, Volume XIV, trans. J. Strachey, The Hogarth Press, London 1957, pp. 243-258. 
In the 1960 and 1970 sestern youth tried to distance themselves primarily from the fetishism of objects. In the 1990s, after the fall of Berlin Wall, so to speak, consumer hedonism was pushed to the forefront and replaced political passion.

The former East of Europe entered this process fully and quickly. In the 200os we rely heavily on objects, they are mobile and transversal; our smartphones and technological gadgets are a hyper overabundance of objects, to such an extent that online social platforms display an incommensurability of emptiness, loss of meaning, the disappearance of ideologies, loneliness, and self-quarantine conditions (not only due to COVID-19). This condition is what Recalcati names the new melancholy. He talks about life connected to senselessness.

Without desire, life is senseless; the body is dead weight to be moved, pushed around. This Occidental subject is incapable of relating to alterity, to otherness. It is symbolically reduced to a proper border of impossibility and clinging to these borders is the last possibility of a proper salvation. As Recalcati writes:

The absence of boundaries inherent in the freedom of the hypermodern turbo consumer has gradually translated into a widespread feeling of anxiety caused by the loss of stable symbolic reference points, but above all it has given rise to a new demand for protection and security. We have thus gone from a manic emphasis on the dissolution of banks and borders, to the need for their re-establishment and security enhancement ${ }^{63}$

Again, we see this melancholy palpably in the form of silence and the failure to act, with many EU citizens inert in the face of what is happening to refugees again in 2020 (as was the cataclysmic situation in September 2020 when fires destroyed Greece's largest migrant camp, an overcrowded facility on the island of Lesbos, leaving nearly 13,00o people without shelter). Instead of revolt and action, what mattered and today only matters is, as Recalcati says, the syndrome that has at its centre the protection of EU citizens' biopolitical lives. This protection of our biopolitical lives in the Occident is fully embedded in the barbed wire and closure of Europe, the EU in Fortress Europe.

63 Recalcati, Le nuove melanconie, p. xi; trans. M. Gržinić. 
The walls and barbed wire are the new objects of investment of the EU's citizens. This entails a demand for an excess of immunization. In classical Freudian psychoanalytic theory, ${ }^{64}$ Todestrieb, the death drive, is the drive toward death and self-destruction. Under this death drive we see an excess of immunization, which transforms into an autoimmune illness. An autoimmune disease is a condition in which the immune system mistakenly attacks a healthy body, which leads to destroying and abandoning any other body or bodies seen as a disease or threat. Fortress Europe is, therefore, also a specific quarantine against refugees. In March 2020 this escalated due to Covid-19 and slowly transformed first Italy and then gradually other EU states into state-imposed quarantine(s).

In the biopolitical condition of Fortress EU, the death drive (Thanatos) is the politics of death that seems to reside only in the Occidental subjective intimacy.

However, we can see that this death drive, which opposes Eros, the tendency toward survival, propagation, sex, and other creative, life-producing drives, changes from preservation (as it is still presented) to destruction. From its intimacy, it externalizes itself by means of real fences, walls, military war machineries, pure destructions, immobilization, and ultimately the death of thousands of refugees. Still, through biopolitical optics, thanathopolitics is not an enemy that undermines life from the outside, but something that is internally produced by life. In the occidental discourse, thanatopolitics is the knot that ties together the death drive and the desire to live.

At this point we have to clarify the difference between thanathopolitics and necropolitics, which cover each other in the Occidental theoretical imaginary too easily, or thanatopolitics is used as a form of a substitute notion for performing a continuity with biopolitics. ${ }^{65}$

64 See Sigmund Freud, Beyond the Pleasure Principle, trans. James Strachey, W. W. Norton \& Company, New York and London 1961; Sigmund Freud, Civilization and Its Discontents, trans. James Strachey, W. W. Norton \& Company, New York and London 1961.

65 See Marina Gržinić, "Introduction: Burdened by the Past, Rethinking the Future. Eleven Theses on Memory, History, and Life," in Opposing Colonialism, Antisemitism, and TurboNationalism: Rethinking the Past for New Conviviality, ed. M. Gržinić, J. Pristovšek, S. Uitz, Cambridge Scholars Publishing, Newcastle upon Tyne 2020, pp. 1-21. 
In short, the trouble, a serious trouble (as Judith Butler would say), with THANATOPOLITICS IS THAT IT IS A PURE OCCIDENTAL (REGIME OF WHITENESS) CATEGORY. In such a situation, refugees are not at all important as everything is centred on this preservation, which in the end is pure destruction. This is why thousands of refugees are kept on Greek islands in the ultimate subhuman conditions of life or left in the limbo of Bosnia and Herzegovina, which itself is a state (in the middle of Europe) in a state of a limbo.

Thanatopolitics is a pure occidental category that spreads like a deadly contagious virus from the intimacy of the Occidental subject into the neoliberal global world, which literally exports contagion into other places, or this contagion has already been contracted through the legacy of Western colonialism (such as imposed on Africa).

The vertiginous presence of death is the result of a life without consciousness of Occidental (proper) vulnerability, which is pathological, centred on itself, and incapable of having a relation to others. Now we come to NECROPOLITICS. It is a pure EXTERNALIZATION OF THANATOPOLITICS. Necropolitics is the regime of neoliberalism's fake vitalism that has also cut the ties with the categories of the negative. ${ }^{66}$

Furthermore, we no longer witness protests by young people in the EU's public spaces (let's say in thousands peacefully protesting) against what is going on with the refugees. It is a psychosis situation that is a situation entailing a total self-relation to itself only, i.e. a deadly form of social autism. Although we can think that this is not the place to propose such a point for further discussion, this is an important issue that needs to be emphasized. Why? Because the outcome of the current state of things is the utter neoliberal, capitalist, biopolitical inability to have any relation with the Other, which is fully drenched in the necrocapitalist, neoliberal, capitalist, deadly machinery.

This circumstance is precisely captured by Recalcati:

The apparently manic inclination of the capitalist's discourse has reinforced a neo-melancholic inclination in young people, who tend to let themselves be ab-

66 Ibid. 
sorbed by the ever-present presence of an object, transforming the object into an object-Thing. It is no longer the object that appears against the background of the mourning of the Thing, but it is the object-Thing that melancholically denies that mourning. While the exciting impulse of the maniacal discourse pushes towards an unceasing exchange of the object in a succession of fragmented presents without historical continuity, this new and particular adhesiveness to the object - for example, to the technological object - reveals the undercurrent of this euphoric thrust: the neo-melancholic bonding to the object, the impossibility of sustaining its loss, the rejection of the mourning of the Thing. [...] The world of the object-Thing replaces the world of encounter with the Other and its inevitable turbulence. ${ }^{67}$

In short, and again, what is going on with the refugees is actually deeply connected with the terrifying modulation of the Occident.

\section{References}

Baudrillard, Jean, In the Shadow of the Silent Majorities, Jean Baudrillard and Semiotext(e), New York 1983

- Simulacra and Simulation, trans. Sheila Faria Glaser, University of Michigan Press, Ann Arbor 1994

Coole, Diana and Samantha Frost (eds.), New Materialisms: Ontology, Agency, and Politics, Duke University Press, Durham and London 2010

DeFazio, Kimberly, “The Spectral Ontology and Miraculous Materialism”, The Red Critique (15/2014), available at: http://www.redcritique.org/WinterSpring2014/spectralontologyandmiraculousmaterialism.htm

Feagin, Joe R., “Whiteness as a Managerial System: Race and the Control of U.S. Labor”, Monthly Review 64 (8/2013), available at: http://monthlyreview.org/author/joerfeagin/

Ferrando, Francesca, "Posthumanism, Transhumanism, Antihumanism, Metahumanism, and New Materialisms: Differences and Relations”, Existenz 8 (2/2013), pp. 26-32

Foucault, Michel, The Foucault Effect: Studies of Governmentality, The University of Chicago Press, Chicago 1991

Freud, Sigmund, Beyond the Pleasure Principle, trans. James Strachey, W. W. Norton \& Company, New York and London 1961

- Civilization and Its Discontents, trans. James Strachey, W. W. Norton \& Company, New York and London 1961

${ }_{67}$ Recalcati, Le nuove melanconie, p. 141, trans. M. Gržinić. 
- "Mourning and Melancholia”, in The Standard Edition of the Complete Psychological Works of Sigmund Freud, Volume XIV, trans. J. Strachey, The Hogarth Press, London 1957

Gilroy, Paul, Against Race: Imagining Political Culture beyond the Color Line, Harvard University Press, Cambridge, Massachusetts 2000

- “There Ain't No Black in the Union Jack": The Cultural Politics of Race and Nation, University of Chicago Press, Chicago 1991

Gomoll, Lucian, “Posthuman Performance: An Feminist Intervention”, Total Art Journal 1 (1/2011), available at: http://totalartjournal.com/archives/1764/posthuman-performance/

Gržinić, Marina, V vrsti za virtualni kruh: čas, prostor, subjekt in novi mediji v letu 2000 [In line for virtual bread: Time, space, subject, and new media in the year 2000], Znanstveno in publicistično središče, Ljubljana 1996

- "Introduction: Burdened by the Past, Rethinking the Future. Eleven Theses on Memory, History, and

Life," in Opposing Colonialism, Antisemitism, and Turbo-Nationalism: Rethinking the Past for New Conviviality, ed. M. Gržinić, J. Pristovšek, S. Uitz, Cambridge Scholars Publishing, Newcastle upon Tyne 2020

- "Real and Virtual Spaces: Confrontations and Exchange”, 2005, available at: https:// www.helsinki.fi/sites/default/files/atoms/files/grzinic.pdf

Gržinić, Marina and Šefik Tatlić, Necropolitics, Racialization, and Global Capitalism: Historicization of Biopolitics and Forensics of Politics, Art, and Life, Lexington Books, Lanham 2014

Hartman, Saidiya V., Scenes of Subjection: Terror, Slavery, and Self-Making in NineteenthCentury America, Oxford University Press, New York 1997

Harman, Graham, Object-Oriented Ontology: A New Theory of Everything, Penguin Books Ltd, London 2018

Haraway, Donna, "Manifesto for Cyborgs: Science, Technology, and Social Feminism in the 1980s", Socialist Review 80 (1985)

- Simians, Cyborgs, and Women: The Re-invention of Nature, Free Association Press, London 1991

hooks, bell, Feminist Theory: From Margin to Center, South End Press, Boston 1984

- "Representing Whiteness in the Black Imagination”, Cultural Studies, ed. L. Grossberg, C. Nelson, P. A. Treichler, Routledge, New York 1992

International Criminal Tribune for the Former Yugoslavia, "Srebrenica Genocide: No Room for Denial”, available at: https://www.icty.org/en/outreach/documentaries/ srebrenica-genocide-no-room-for-denial (accessed 16 November 2020)

Jay, Martin, Force Fields: Between Intellectual History and Cultural Critique, Routledge, New York and London 1993 
Kroker, Arthur and David Cook, The Postmodern Scene: Excremental Culture and HyperAesthetics, St. Martin's Press, New York 1986

LaBare, Joshua (Sha), "Review of What is Posthumanism?”, Science Fiction Film and Television 4 (1/2011), pp. 136-140

Lévy, Pierre, “Toward Super-language”, ISEA 94: The 5th International Symposium on Electronic Art on Electronic Art Catalogue, ed. M. Tarkka, University of Art and Design Helsinki, Helsinki 1994

López, Santiago Petit, La movilización global: Breve tratado para atacar la realidad [Global mobilisation: A brief treatise for attacking reality], Editorial Traficantes de Sueños, Barcelona 2009

Martinot, Steve, “The Coloniality of Power: Notes Toward De-Colonization”, available at: https://www.ocf.berkeley.edu/ marto/coloniality.htm (accessed 16 November 2020)

Mbembe, Achille, "Necropolitics", Public Culture 15 (1/2003), pp. 1-40

Recalcati, Massimo, Le nuove melanconie: Destini del desiderio nel tempo ipermoderno [The new melancholies: Fates of desire in hypermodern time], Raffaello Cortina Editore, Milano 2019

Roediger, David R. and Elizabeth D. Esch, The Production of Difference: Race and the Management of Labor in U.S. History, Oxford University Press, New York 2012

Quijano, Aníbal, “Coloniality and Modernity/Rationality”, Cultural Studies 21 (2-3/2007), pp. $168-178$

Weibel, Peter, "Ways of Contextualisation, or The Exhibition as a Discrete Machine", in Place, Position, Presentation Public, ed. I. Gevers, Jan van Eyck Akademie and De Balie, Maastricht and Amsterdam 1993 